RAFA $ヒ$ WILLA

Instytut Europeistyki UJ

\title{
Droga do członkostwa w Unii Europejskiej — przykład Polski
}

Drzystąpienie Polski do Unii Europejskiej (UE) było konsekwentnie popierane przez wszystkie podstawowe siły polityczne kraju bez wzglę$\mathrm{du}$ na zmiany u steru władzy zachodzące w ciągu lat 90 . XX w. Integracja Polski ze strukturami unijnymi jawiła się generalnie jako proces nieuchronny i nieodwracalny, jako uczestnictwo w głównym nurcie procesów zachodzących wówczas w Europie. Odrzucenie tego kierunku polskiej polityki zagranicznej oznaczałoby dobrowolne skazanie się na marginalizację w coraz bardziej integrującym się otoczeniu. Perspektywa poszerzenia Unii Europejskiej o państwa Europy Środkowo-Wschodniej (EŚ-W) była również największym wyzwaniem politycznym, przed jakim stanęła ona od początków swej historii ${ }^{1}$. Stanowiła też swego rodzaju powrót do źródeł chrześcijańskiej jedności Europy i zarazem do idei, które przyświecały „ojcom" integracji europejskiej - stworzenia na kontynencie warunków pokojowej współpracy narodów zamieszkujących wszystkie jej części²

${ }^{1}$ Por. S. Stebelski, Zmiana układu sił w UE po przyjęciu Polski i innych krajów Europy Środkowej $i$ Wschodniej, w: Polska w Unii Europejskiej, Stanisław Miklaszewski (red.), Kraków 1999, s. 17.

2 „W rozważaniach, jakie prowadzono na przestrzeni wieków nad sposobami zapewnienia pomyślności nacjom europejskim w drodze ich współdziałania w tworzeniu ładu i porządku na kontynencie, za naturalny uznawano udział w podejmowanych przedsięwzięciach Polaków, Czechów i Węgrów. Paradoksem historii była ich niemożność włączenia się w budowę wspólnej Europy na przełomie czwartego i piątego dziesięciolecia poprzedniego stulecia, kiedy to ich zachodni sąsiedzi do tego dojrzeli. Potrzeba było aż 40 lat, aby zlikwidowane zostały źródła europejskich podziałów, a Polska, Czechy i Węgry, razem z innymi państwami Europy Środkowej i Wschodniej, uzyskały szansę dołączenia do swoich zachodnich partnerów", w: tamże, s. 14. 
W przypadku dotychczasowych rozszerzeń UE głównym motywem integracji kraju kandydującego był motyw ekonomiczny w postaci oczekiwania wzrostu efektywności gospodarczej kraju oraz poprawy poziomu życia ludności. Jakie motywy kierowały dziesięcioma państwami kandydackimi? Wydaje się prawdopodobnym, że kraje Europy Środkowo-Wschodniej, dążąc do uzyskania członkostwa w UE, kierowały się przede wszystkim następującymi motywami ${ }^{3}$ : po pierwsze, członkostwo w UE oznaczało przystąpienie do zachodniej wspólnoty dobrobytu i bezpieczeństwa, stanowiąc tym samym zabezpieczenie przed powrotem tych państw do rosyjskiej strefy wpływów ${ }^{4}$; po drugie wreszcie, członkostwo w UE było najlepszym sposobem na uzyskanie dostępu do rynku wewnętrznego UE. Związanie z Unią umożliwić miało zatem krajom Europy Środkowo-Wschodniej odejście od ich relatywnie niskiego poziomu rozwoju oraz reintegrację z gospodarką światową ${ }^{5}$.

Wobec powyższego należałoby się zastanowić, jak wygląda procedura akcesyjna do UE? Jak wyglądała, przez ostatnich kilkanaście lat, droga Polski do członkostwa w UE? Jak ogromny wysiłek włożyły obie strony w procesy integracyjne? Te wszystkie pytania są niezwykle istotne, gdyż tworzą one naszą teraźniejszość, dlatego też w poniższej pracy autor spróbuje na nie odpowiedzieć.

\section{Okres przed podpisaniem Układu Europejskiego}

„W latach 1952-1970, czyli do momentu dojścia do władzy Edwarda Gierka, między Polską a Wspólnotami Europejskimi (WE) nie było żadnych stosunków dyplomatycznych. W tym okresie relacje pomiędzy obiema stronami były antagonistyczne i konfliktowe, głównie za sprawą naszych władz”. Nie uznawały one WE, uważając je za twór „reakcyjno-burżuazyjny", za polityczno-gospodarcze ramię NATO. Dopiero od lat 70. agresyw-

\footnotetext{
${ }^{3}$ Por. H. Tendera-Właszczuk, Rozszerzenie Unii Europejskiej na Wschód. Polska na tle innych krajów, Warszawa 2001, s. 109; A. Chodubski, Uwarunkowania cywilizacyjne przystapienia Polski do Unii Europejskiej, w: Polska. Między Zachodem a Wschodem $w$ dobie integracji europejskiej, Maria Marczewska-Rytko (red.), Lublin 2001, s. 126.

${ }^{4}$ Jak wskazuje Stanley Hoffman „rozszerzenie UE na wschód było konieczne, by zapewnić stabilność w kłopotliwej części kontynentu oraz w celu zabezpieczenia „raczkującej” tam demokracji”, S. Hoffman, Toward a Common European Foreign and Security Policy?, w: „Journal of Common Market Studies", nr 2, 2000, s. 196. Por. G.M. Thornton, The European Union: Teleology and Some Challenges of the Eastern Enlargement, s. 11, dostępne: http://aei.pitt.edu/ 1989/01/PB19.PDF [15.06.2007].

${ }^{5}$ Por. P. Brenton, The Economic Impact of Enlargement on the European Economy: Problems and Perspectives, s. 13, dostępne: http://aei.pitt.edu/1821/01/WD188.PDF [15.06.2007].

${ }^{6}$ J. Kułakowski, Strona Polska w negocjacjach z UE, w: Polska droga do Unii Europejskiej. Ekonomiczne i społeczne konsekwencje integracji Polski z UE, Helena Tendera-Właszczuk (red.), Katowice 1997, s. 9.
} 
ność w stosunku do WE zaczęła się stopniowo zmniejszać, jak również zaczęły pojawiać się nieformalne i prywatne kontakty pomiędzy przedstawicielami władz Polski i WE.

25 czerwca 1988 r. między ówczesnymi Wspólnotami Europejskimi i Radą Wzajemnej Współpracy Gospodarczej (RWPG) podpisano deklarację normalizującą relacje między tymi ugrupowaniami. Deklaracja owa stała się podstawą do nawiązania oficjalnych stosunków dyplomatycznych między Polską a Wspólnotami Europejskimi - a więc dopiero, gdy RWPG uznała Wspólnoty, uznał je także rząd polski. Jednakże nawiązanie stosunków dyplomatycznych między Polską a Wspólnotami miało miejsce we dopiero we wrześniu 1988 r. Nastąpiło to jeszcze przed przełomem systemowym w Polsce i całym Bloku Wschodnim - rozpoczęły się wówczas pierwsze negocjacje pomiędzy PRL a Wspólnotami Europejskimi, które dotyczyły Umowy o Handlu i Współpracy.

Wkrótce po rozpoczęciu procesu transformacji systemowej i gospodarczej rząd premiera Tadeusza Mazowieckiego podjął decyzję o zacieśnieniu powiązań ze Wspólnotami Europejskimi. Pierwszy demokratyczny polski rząd umieścił kwestię integracji europejskiej wśród najważniejszych zadań polskiej polityki zagranicznej i już w lipcu 1989 r. utworzono w Brukseli Przedstawicielstwo Rzeczypospolitej Polskiej przy Wspólnotach Europejskich (ambasadorem został Jan Kułakowski). Był to bardzo wymierny krok polityczny wskazujący na zamiar (instytucjonalnego) powiązania Polski ze strukturami Wspólnot.

Fakt zaistnienia pierwszych wiarygodnych wyborów w powojennej Polsce oraz zapowiedź wolnorynkowych przemian w naszym kraju spotkały się z entuzjastycznym przyjęciem przez zachodnioeuropejskie elity polityczne. „W dniach 14-15 lipca 1989 r., podczas paryskiego szczytu siedmiu najbardziej uprzemysłowionych państw świata (G7), podjęto decyzję o przyznaniu pomocy ekonomicznej dla Polski i Węgier - państw, które najwcześniej podjęły trudną próbę przeprowadzenia reform ustrojowych. Koordynację tej pomocy powierzono Komisji Wspólnot Europejskich. Rada Ministrów Wspólnot Europejskich uchwaliła 18 grudnia 1989 r. stosowne rozporządzenie, które stworzyło podstawę prawną dla programu PHARE, którego pomoc została później rozszerzona na inne państwa Europy Środkowej i Wschodniej"'.

Umowę o Handlu i Współpracy podpisano ostatecznie w Warszawie 19 września 1989 r. Oznaczało to zamknięcie długiego okresu bezumownych stosunków handlowych i zapoczątkowanie nowych form współpracy

\footnotetext{
${ }^{7}$ Negocjacje członkowskie. Polska na drodze do Unii Europejskiej, Warszawa 2000, s. 9.
} 
między obu stronami. „Była to niepreferencyjna umowa zawierająca klauzulę najwyższego uprzywilejowania $\mathrm{w}$ handlu dla obu stron. Przewidywała ona stopniowe znoszenie ograniczeń ilościowych nakładanych przez Wspólnoty w stosunku do importu towarów pochodzących z Polski, aż do ich całkowitego wyeliminowania w 1994 r. Wskutek umowy już w 1990 r. państwa członkowskie Wspólnot stały się głównym partnerem handlowym Polski"8.

Kilka miesięcy później, 25 maja 1990 r., Polska złożyła w Brukseli oficjalny wniosek o rozpoczęcie negocjacji umowy o stowarzyszeniu ze Wspólnotami. 22 grudnia 1990 r. Rada Ministrów Wspólnot Europejskich wydała dyrektywy pozwalające Komisji Wspólnot Europejskich na podjęcie rokowań z rządem RP. Rezultatem prowadzonych rozmów stał się Układ Europejski ustanawiający stowarzyszenie między Rzeczpospolita Polska a Wspólnotami Europejskimi i ich państwami członkowskimi, zwany Układem Europejskim.

\section{Układ Europejski}

Przygotowania do podjęcia rozmów ze Wspólnotami w sprawie stowarzyszenia rząd rozpoczął już 26 stycznia 1991 r., tworząc przy Radzie Ministrów stanowisko Pełnomocnika Rządu do Spraw Integracji Europejskiej oraz Pomocy Zagranicznej (został nim wtedy Jacek Saryusz-Wolski). Od lutego do listopada 1991 odbyło się osiem rund negocjacyjnych, zakończonych 22 listopada parafowaniem Układu Europejskiego o ustanowieniu stowarzyszenia między Rzeczpospolitą Polską a Wspólnotami Europejskimi i krajami członkowskimi. Układ Europejski, a w zasadzie układy, zostały podpisane 16 grudnia $1991 \mathrm{r}$.

Pierwsza umowa, handlowa, tworząca strefę wolnego handlu, weszła w życie 1 marca 1992 r. Została ona wynegocjowana przez Komisję z mandatu państw członkowskich i mogła wejść w życie natychmiast, bez ratyfikacji przez poszczególne państwa. Reszta dyspozycji politycznych, instytucjonalnych, o współpracy gospodarczej i pomocy finansowej wymagała ratyfikacji PE, Parlamentu Polskiego i 12 parlamentów państw członkowskich. Okres wejścia w życie tej części układu przedłużył się. Prezydent Lech Wałęsa ratyfikował tę umowę 20 października 1992 r., a 13 grudnia 1993 zakończono ratyfikację unijną, wobec czego z dniem 1 lutego 1994 Układ Europejski zaczął obowiązywać w całości.

Układ Europejski był jednym z najważniejszych porozumień spośród wszystkich umów zawartych przez Polskę po 1989 r. z jej partnerami gospodarczymi, zarówno z uwagi na bardzo szeroki zakres uregulowań, jak też ze względu na spodziewane istotne konsekwencje dla polskiej gospodarki. Ure-

\footnotetext{
${ }^{8}$ Tamże, s. 9.
} 
gulował on stosunki Polski z najsilniejszym ugrupowaniem integracyjnym na świecie, z ugrupowaniem będącym zarazem naszym największym partnerem ekonomicznym (udział państw Wspólnot przekroczył 60\% polskiego eksportu i importu) $)^{9}$.

Umowa ta w zasadniczy sposób rozszerzyła ramy współpracy ekonomicznej i politycznej Polski ze Wspólnotami Europejskimi ${ }^{10}$. Obok tzw. dialogu politycznego, regulowała ona kwestie wzajemnego handlu, przepływu usług, pracowników, kapitału i zakładania przedsiębiorstw. Zawierała też postanowienia o harmonizacji przepisów prawnych w Polsce do legislacji wspólnotowej. Przewidywała ponadto szeroką współpracę gospodarczą, finansową oraz w dziedzinie kultury, a koncesje udzielone sobie przez strony Układu Europejskiego miały charakter preferencyjny, tzn. nie były rozciągane na innych partnerów handlowych. Jednakże sprawy gospodarcze, choć ze wszech miar bardzo istotne, nie stanowily kwestii pierwszoplanowej, bowiem bodaj najistotniejszym efektem tej umowy było stowarzyszenie Polski ze Wspólnotami Europejskimi. Stworzono w ten sposób instrument zacieśnienia powiązań instytucjonalnych i politycznych ${ }^{11}$.

\footnotetext{
9 „Układ ten niewątpliwie przyczynił się także do ustabilizowania warunków polskiej wymiany handlowej. Ważne było także znaczenie tego układu dla procesu transformacji w Polsce. Zobowiązania Układu Europejskiego oznaczały przyjęcie pewnego „drogowskazu” przemian systemowych. Wymusiły one kontynuację reform strukturalnych, czyniąc tym samym nieodwracalnymi wdrażane reformy rynkowe", w: E. Kawecka-Wyrzykowska, Obecny etap integracji Polski z Unia Europejska, w: Integracja Polski z Unia Europejską. Wyzwania i dylematy, Stefan Pastuszka, Bogdan Kawałko (red.), Zamość 1998, s. 20.

${ }^{10}$ Cele Układu Europejskiego, określone w art. 1, są następujące: a) ustanowienie odpowiednich ram dialogu politycznego, który umożliwi rozwój bliskich stosunków politycznych między stronami; b) popieranie rozwoju handlu i harmonijnych stosunków gospodarczych między stronami w celu sprzyjania dynamicznemu rozwojowi gospodarczemu i dobrobytowi w Polsce; c) stworzenie podstawy dla pomocy finansowej i technicznej Wspólnoty dla Polski; d) stworzenie właściwych ram dla stopniowej integracji Polski ze Wspólnotą; e) popieranie współpracy w dziedzinie kultury. Por. E. Kawecka-Wyrzykowska, Polska $w$ drodze do Unii Europejskiej, Warszawa 1999, s. 19-20; A. Harasimowicz, Aspekty polityczne stowarzyszenia Polski ze Wspólnotami Europejskimi, w: Polska w procesie integracji ze Wspólnotami Europejskimi, Zofia Wysokińska (red.), Warszawa/ Łódź 1994, s. 20.

${ }^{11}$ Jednakże Polska od początku negocjacji deklarowała chęć pełnego członkostwa w ugrupowaniu. Było jednak oczywiste, że w ówczesnych realiach politycznych cel ten był nierealny. Wspólnota nie była jeszcze gotowa na przyjęcie choćby politycznej deklaracji gotowości do rozszerzenia ugrupowania o Polskę i inne kraje, z którymi wówczas, równolegle, toczyły się negocjacje $\mathrm{w}$ sprawie ich stowarzyszenia. $\mathrm{W}$ trakcie negocjacji układu stowarzyszeniowego zespół negocjacyjny Komisji WE, kierując się mandatem otrzymanym od Rady Ministrów WE, nie przyjął nawet postulatu, aby wyraźnie zapisać w umowie, iż członkostwo Polski w WE jest uzgodnionym celem obu stron Układu. Dopiero po długiej i ciężkiej walce z przedstawicielami Wspólnot Europejskich udało się skłonić ich do zapisania w Preambule Układu Europejskiego jednostronnej deklaracji stanowiącej, iż ostatecznym celem Polski jest pełne członkostwo we Wspólnocie, a stowarzyszenie pomoże Polsce ten cel osiągnąć.
} 


\section{Przygotowania do rozszerzenia Unii Europejskiej}

W 1992 r. polski rząd podjął kilka inicjatyw, wspólnie z Węgrami i (ówczesną) Czechosłowacją, aby skłonić Komisję WE do sprecyzowania warunków członkostwa. We wspólnym memorandum, tzw. Memorandum Wyszehradzkim $^{12}$, przedłożonym Wspólnotom 11 listopada, podkreślano, że kraje te w pełni popierają cele przyświecające UE i dążą do pełnego członkostwa w niej, a stowarzyszenie może wydatnie przybliżyć je do tego celu. 28 października tegoż roku, na spotkaniu państw Grupy Wyszehradzkiej z Radą Europejską (RE) w czasie tzw. szczytu londyńskiego, ponownie zabiegano o konkretyzację warunków członkostwa.

„Rada Europejska w konkluzjach ze spotkania w Edynburgu 11-12 grudnia 1992 r. przyjęła raport Andriessena ${ }^{13}$, ale ustosunkowała się doń dość ogólnikowo. Uznano tam, że jest to pozytywna odpowiedź na memorandum państw Grupy Wyszehradzkiej. Znalazła się tam również zapowiedź, że na szczycie kopenhaskim w czerwcu $1993 \mathrm{r}$. RE podejmie decyzję co do bardziej szczegółowych propozycji zawartych w raporcie Andriessena, mających na celu przygotowanie krajów stowarzyszonych do przystąpienia do UE"14.

Przywódcy państw, już wtedy Unii Europejskiej, na szczycie Rady Europejskiej 21-22 czerwca 1993 r. w Kopenhadze, podjęli bardzo ważną, dla Polski i innych stowarzyszonych krajów Europy Środkowej i Wschodniej, decyzję polityczną. Zadecydowali wówczas wyraźnie i jednoznacznie, że „stowarzyszone kraje Europy Środkowej i Wschodniej, które tego sobie życzą, staną się członkami Unii Europejskiej” oraz, że „przystąpienie nastąpi niezwłocznie po przyjęciu zobowiązań wynikających z członkostwa, w drodze spełnienia warunków politycznych i ekonomicznych"15.

\footnotetext{
${ }^{12}$ Por. Memorandum państw Grupy Wyszehradzkiej, w: „Monitor Integracji Europejskiej”, nr 3, 1995, s. 22-27.

${ }^{13}$ Raport F. Andriessena, wiceprzewodniczącego KE (do stycznia 1993 roku), przygotowany na zamówienie RE, pozytywnie ocenił rozwój stosunków z państwami Grupy Wyszehradzkiej i postulował dalsze pogłębianie dialogu politycznego, co miało lepiej przygotować kraje kandydujące do udziału w procesie integracji europejskiej. Por. A Harasimowicz, dz.cyt., s. 17.

${ }^{14}$ Tamże, s. 18.

${ }^{15}$ Były one następujące: a) osiągnięcie przez kraj kandydujący stabilności instytucji gwarantujących demokrację, rządy prawa, przestrzeganie praw człowieka oraz poszanowanie i ochronę mniejszości narodowych, pluralizm polityczny; b) istnienie sprawnej i otwartej gospodarki rynkowej, jak również zdolność przeciwstawienia się presji konkurencji oraz siłom rynkowym działającym wewnątrz Unii; c) zdolność do przejęcia zobowiązań wynikających z członkostwa, w tym podzielanie celów unii politycznej, gospodarczej i walutowej; d) jednocześnie sformułowano warunek dotyczący samej Unii: każde nowe członkostwo będzie uzależnione od zdolności samej Unii do przyjęcia nowych członków. Por. European Council in Copenhagen, 21-22 June 1993, Conclusions of the Presidency, SN 10/93, Copenhagen, 22 June 1993; E. Kawecka-Wyrzykowska, Ewolucja polityki UE wobec rozszerzenia, w: Stosunki Polski
} 
Pierwszym krokiem, jaki należało poczynić, było złożenie wniosku kraju kandydującego o członkostwo w Radzie Unii Europejskiej. 8 kwietnia 1994 r. Minister Spraw Zagranicznych RP Andrzej Olechowski złożył w Atenach, gdyż Grecja przewodniczyła wówczas Unii, oficjalny wniosek o członkostwo Polski w Unii Europejskiej ${ }^{16}$. Warto zwrócić uwagę, iż nastąpiło to w dwa miesiące po wejściu w życie całego Układu Europejskiego. Złożenie wniosku było doniosłym wydarzeniem politycznym, a przede wszystkim otwierało drogę na konkretne działania zarówno po stronie polskiej, jak i unijnej, ułatwiające pełną integrację Polski ze strukturami europejskimi.

Aby ułatwić przygotowania państw kandydujących do członkostwa w Unii Europejskiej, Rada Europejska podczas szczytu w Essen w dniach 8-10 grudnia 1994 r. przyjęła strategię przedczłonkowską. Głównym jej celem było wsparcie państw stowarzyszonych $\mathrm{w}$ procesie przygotowań do standardów unijnych ${ }^{17}$. W zasadzie strategia ta potwierdziła ustalenia kopenhaskie; Polskie oczekiwania nie zostały więc $\mathrm{w}$ pełni zaspokojone, zabrakło bowiem $\mathrm{w}$ tej strategii kalendarza dochodzenia do członkostwa, a przede wszystkim daty rozpoczęcia negocjacji. Jednakże, biorąc pod uwagę ogólny interes państw kandydujących do Unii, zapadły tu innego typu bardzo ważne dla nich decyzje. Zobowiązano bowiem Komisję Europejską (KE) do przygotowania Białej Księgi, która miała stopniowo przygotować kraje stowarzyszone do integracji z rynkiem unijnym poprzez przyjmowanie wspólnotowego dorobku prawnego.

Na szczycie UE, który odbył się w dniach 23-24 czerwca 1995 r. w Cannes, przywódcy Unii przyjęli tzw. Białą Księgę - raport KE w sprawie przygotowania stowarzyszonych krajów EŚ-W do integracji z jednolitym ryn-

z Unią Europejska, Elżbieta Kawecka-Wyrzykowska (red.), Warszawa 2002, s. 86; I. Pawlas, Wschodnie rozszerzenie Unii Europejskiej. Scenariusz R. Baldwina czy J.D. Sachsa, w: Polska droga do Unii Europejskiej. Ekonomiczne i społeczne konsekwencje integracji Polski z UE, Helena TenderaWłaszczuk (red.), Katowice 1997, s. 51; J. Hughes, G. Sasse, C. Gordon, The Regional Deficit in Eastward Enlargement of the European Union: Top Down Policies and Bottom Up Reactions, s. 10, dostępne: http://www.one-europe.ac.uk/pdf/w29gordon.pdf [15.06.2007].

${ }^{16} \mathrm{~W}$ uzasadnieniu podkreślono, iż, ,proces transformacji gospodarczej, społecznej i politycznej w Polsce zmierza w kierunku umożliwiającym spełnienie warunków przystąpienia do Unii" oraz wskazano, że członkostwo „oznacza utrwalenie przemian demokratycznych, konsolidację transformacji systemowej (...) i będzie służyć utrzymaniu pokoju i stabilności w Europie dzięki eliminacji skutków podziału naszego kontynentu", w: Wniosek Polski o członkostwo w Unii Europejskiej, w: „Monitor Integracji Europejskiej”, nr 3, 1995, s. 38-43.

${ }^{17}$ Do głównych elementów strategii zaliczono: a) dialog strukturalny, czyli możliwość roboczych spotkań ministrów z krajów stowarzyszonych z odpowiednimi członkami z Rady Unii Europejskiej; b) przygotowanie krajów stowarzyszonych do uczestnictwa w rynku wewnętrznym; c) współpracę w zakresie polityki zagranicznej i bezpieczeństwa europejskiego; d) współpracę w sferze ochrony środowiska; e) pomoc techniczną i prawną w ramach programu PHARE; f) wspieranie współpracy regionalnej między państwami stowarzyszonymi. 
kiem unijnym. Dokument ten był „zbiorem kilkuset aktów prawnych prawa wspólnotowego, priorytetowych z punktu widzenia zasad funkcjonowania jednolitego rynku wewnętrznego Unii. Wyróżniono tu 23 sektory, z których każdy został zaprezentowany z punktu widzenia charakteru regulacji, celów i przyjętych metod regulacji. Nie tylko wskazano, ale również dokonano ich hierarchizacji, określając kolejność ich wdrażania przez kraje kandydackie ${ }^{18}$ w podziale na etapy - od tych, tworzących ogólne ramy, zasady i procedury oraz wymagające długotrwałego okresu realizacji, do aktów prawnych o charakterze szczegółowym" ${ }^{19}$. W Białej Księdze przedstawiono również niezbędne warunki funkcjonowania praw, czyli wskazano podstawowe elementy infrastruktury prawnej, pozwalające na skuteczną implementację wskazanych aktów prawnych oraz ich egzekwowanie w celu zapewnienia prawidłowego ich funkcjonowania ${ }^{20}$.

W dokumencie końcowym, przyjętym w Madrycie (15-16 grudnia 1995 r.), Rada Europejska potwierdziła wolę rozszerzenia, wskazując, że jest ono „dla Europy zarówno koniecznością polityczną, jak i historyczną szansą. Zapewni ono stabilizację i bezpieczeństwo na kontynencie, niosąc jednocześnie nowe możliwości wzrostu ekonomicznego oraz ogólny dobrobyt, tak przyszłym, jak i obecnym członkom Unii”"21. Zapadła również decyzja o rozpoczęciu negocjacji z Maltą i Cyprem, a wstępna faza rozmów obu zaproszonych krajów miała zostać połączona z początkiem rokowań z państwami Europy Środkowej i Wschodniej.

Na szczycie w Madrycie przywódcy Unii zwrócili się także do Komisji Europejskiej o przygotowanie tzw. Opinii dotyczących wniosków o członkostwo (AVIS) Polski i innych krajów kandydujących do UE, a także całościowego raportu na temat rozszerzenia. Opinia ta, zgodnie $\mathrm{z}$ obowiązującą procedurą, miała być podstawą podjęcia decyzji o rozpoczęciu negocjacji $\mathrm{z}$ danym krajem. Elementem służącym jej wypracowaniu były pytania w specjalnym kwestionariuszu, nad którym KE pracowała około pół roku. Obejmował on wszystkie dziedziny polityki UE: od polityki celnej po współ-

\footnotetext{
${ }^{18}$ Obowiązek dostosowania prawa polskiego do prawa wspólnotowego przewidziano już w Układzie Europejskim. Jednakże w Białej Księdze w sposób bardziej szczegółowy określono sfery koniecznych dostosowań, a także niezbędne do tego środki.

${ }^{19}$ H. Tendera-Właszczuk, dz.cyt., s. 143.

${ }^{20}$ Oficjalne stanowisko w sprawie Białej Księgi strona polska zajęła w lipcu 1995 roku w „Harmonogramie działań dostosowujących polski system prawny do zaleceń Białej Księgi Komisji Europejskiej w sprawie integracji z jednolitym rynkiem Unii Europejskiej”. Stał się on podstawowym aktem rządowym służącym harmonizowaniu prawa polskiego w obrębie rynku wewnętrznego UE. Harmonogram został zaakceptowany przez Radę Ministrów RP w dniu 15 lipca 1997 roku.

${ }^{21}$ Dokument końcowy Rady Europejskiej w Madrycie, w: „Monitor Integracji Europejskiej”, nr 5, 1995 , s. 48
} 
pracę w zakresie wymiaru sprawiedliwości i spraw wewnętrznych. Tematyka tych pytań (łącznie ponad 200) była więc dość zróżnicowana i na różnym poziomie szczegółowości, a celem tego „prześwietlenia” było uzyskanie informacji odnośnie sytuacji polityczno-gospodarczej danego państwa.

Dnia 26 kwietnia 1996 r. Komisja Europejska przekazała ten kwestionariusz Polsce, jak i innym państwom starającym się o członkostwo w UE. Do udzielenia odpowiedzi polski rząd przygotował się niezwykle starannie. Decyzją Rady Ministrów z 5 marca 1996 r. ówczesny Pełnomocnik Rządu ds. Integracji Europejskiej oraz Pomocy Zagranicznej został zobowiązany do koordynacji prac związanych z opracowaniem odpowiedzi na kwestionariusz Komisji ${ }^{22} .26$ lipca 1996 r., po intensywnych pracach, Minister Spraw Zagranicznych Dariusz Rosati przekazał Szefowi Delegacji Europejskiej, Rolfowi Timansowi, angielską wersję dokumentu (łącznie około 2300 stron). Stał się on podstawą dla KE przy sporządzaniu opinii w sprawie wniosku Polski o członkostwo w UE.

16 lipca 1997 r. Komisja Europejska przedstawiła na forum Parlamentu Europejskiego opinie dotyczące wniosków o członkostwo w Unii złożonych przez kraje Europy Środkowo-Wschodniej. Komisja rekomendowała podjęcie negocjacji z sześcioma krajami: Czechami, Cyprem, Estonią, Słowacją, Węgrami i z Polską. Wraz z tymi Opiniami Komisja zaprezentowała zestaw dokumentów, w których zaproponowała zmiany w zasadach funkcjonowania Unii tak, aby UE była gotowa do przyjęcia nowych, słabiej rozwiniętych partnerów (cały pakiet nosił nazwę AGENDA 2000). Propozycje zmian dotyczyły zwłaszcza wspólnej polityki rolnej, budżetu Unii oraz zasad funkcjonowania funduszy strukturalnych, a więc trzech dziedzin, w których skutki rozszerzenia byłyby najbardziej odczuwalne ${ }^{23}$.

Opinia KE o Polsce ${ }^{24}$ (AVIS) zawierała bardzo pozytywną ocenę ogromnego wysiłku, jakiego dokonano w naszym kraju w ostatnich latach. KE podkreśliła z uznaniem ogromną skalę przeobrażeń systemowych i reform

\footnotetext{
${ }^{22}$ Jego działalność polegała na zbieraniu informacji z poszczególnych ministerstw i urzędów centralnych (odpowiedzi na niektóre pytania byty przygotowywane w kilku resortach) oraz przedstawianiu Radzie Ministrów stosownych opinii w danym zakresie. Cały pakiet odpowiedzi na kwestionariusz, które zawarto w 26 tomach, został zatwierdzony przez Radę Ministrów 15 lipca 1996 roku.

${ }^{23}$ Por. E. Kawecka-Wyrzykowska, Obecny etap integracji Polski z Unia Europejska, w: Integracja Polski z Unia Europejska. Wyzwania i dylematy, Stefan Pastuszka, Bogdan Kawałko (red.), Zamość 1998, s. 22.

${ }^{24}$ Był to obszerny, liczący ponad 100 stron dokument, w którym zawarto szczegółowe oceny o stopniu rozwoju i dostosowania do wspólnotowych wymogów różnych dziedzin życia społecznego i gospodarczego danego kraju. Por. W. Dugiel, Warunki członkostwa w UE $i$ ich spełnianie przez Polskę, w: Stosunki Polski z Unia Europejską, Elżbieta Kawecka-Wyrzykowska (red.), Warszawa 2002, s. 97.
} 
gospodarczych oraz społecznych, zbliżających nasz kraj do standardów UE. Stwierdzono, że Polska ma cechy demokracji o stabilnych instytucjach gwarantujących praworządność, prawa człowieka i poszanowanie mniejszości, a także może być uważana za funkcjonującą gospodarkę rynkową, która będzie w stanie sprostać presji konkurencji i sił rynkowych w Unii w średnim okresie czasu. Jeżeli chodzi o inne aspekty acauis communautaire uznano, że nie powinna mieć problemów ze spełnieniem w ciągu kilku lat wymagań w dziedzinach: edukacji, szkoleń i młodzieży, badań i rozwoju technicznego, statystyki, małych i średnich przedsiębiorstw i polityki celnej. Jednocześnie wskazano dziedziny, w których działania dostosowawcze wymagały intensyfikacji ${ }^{25}$.

Na szczycie Unii Europejskiej w Luksemburgu (12-13 grudnia 1997 r.) podjęto kolejną bardzo istotną decyzję polityczną - decyzję o rozpoczęciu rokowań z państwami wymienionymi przez Komisję Europejską, ustalając jednocześnie, że rokowania akcesyjne rozpoczną się w końcu marca 1998 r. Przyjęto wtedy także strategię przedczłonkowską w postaci programu „Partnerstwo dla Członkostwa". Wyznaczono w nim obszary priorytetowe $\mathrm{w}$ dochodzeniu do członkostwa w Unii, środki finansowe na ich realizację i zasady udzielania pomocy. Program ten tworzył ogólne ramy procesu dostosowawczego przez wykorzystanie procedur już przyjętych (np. Układy Europejskie, PHARE, dialog strukturalny), ale także przez udział państw stowarzyszonych w programach Wspólnotowych i procedurach unijnych.

UE zaoferowała Polsce i innym krajom stowarzyszonym pomoc finansową na wsparcie procesu dostosowań w okresie przedakcesyjnym. Finansowym instrumentem wspierania procesu przygotowań do członkostwa stał się m.in. zmodyfikowany program PHARE. Obok środków z tego programu dostosowania do członkostwa były finansowane $\mathrm{z}$ innych środków, w tym preferencyjnych kredytów instytucji międzynarodowych i krajowych środków budżetowych. Ponadto od 2000 r. można było liczyć na środki z dwóch nowopowstałych funduszy przedakcesyjnych: SAPARD i ISPA ${ }^{26}$.

\footnotetext{
${ }^{25}$ M.in.: rolnictwo, infrastruktura (zwłaszcza transportowa), ochrona środowiska, brak reformy systemu emerytalnego, zbyt wolna prywatyzacja, zbyt wolne przyjmowanie acquis communataire, niedorozwój i ograniczenia w sektorach bankowym i telekomunikacyjnym, rybołówstwo i ochrona konsumentów. Szczegółowe informacje o AVIS w: T. Żółtowski, AVIS. Kryteria przystapienia Polski do Unii Europejskiej, w: Polska droga do Unii Europejskiej. Ekonomiczne i społeczne konsekwencje integracji Polski z UE, Helena Tendera-Właszczuk (red.), Katowice 1997, s. 37-41. Por. Helena Tendera-Właszczuk, dz.cyt., s. 125-126; W. Dugiel, dz.cyt., s. 98-115.

${ }^{26}$ Pierwszy współfinansował przedsięwzięcia z zakresu restrukturyzacji i modernizacji wsi i rolnictwa; pomyślany jest jako prekursor zreformowanego Europejskiego Funduszu Orientacji i Ukierunkowania Rolnictwa oraz Instrumentu Finansowego Rybołówstwa; drugi współfinansował działania z zakresu dużych inwestycji infrastrukturalnych w korytarzach europejskich oraz inwestycje w sektorze ochrony środowiska o znaczeniu krajowym i europejskim; zasady tego funduszu były prawie tożsame z zasadami Funduszu Spójności.
} 


\section{Przebieg negocjacji akcesyjnych}

Negocjacje o członkostwo w Unii Europejskiej były złożone i wymagały znacznego wysiłku administracji obydwu stron: zarówno państwa kandydującego $^{27}$, jak i samej Unii. Oficjalnie negocjacje miedzy Polską a Unią Europejską rozpoczęły się 31 marca $1998 \mathrm{r}^{28}$ Polska, podobnie jak inne państwa dążące do członkostwa w Unii Europejskiej, rozpoczęła je, 3 kwietnia 1998 r. w Brukseli, od przeglądu prawa krajowego (screening) pod kątem jego zgodności z dorobkiem prawnym Wspólnot. „W czasie screeningu obowiązywał podział na dwie grupy krajów: Polskę, Czechy, Węgry, Słowenię, Estonię i Cypr, które rozpoczęły negocjacje 31 marca 1998 r., oraz Słowację, Bułgarię, Rumunię, Litwę i Łotwę. Dla przeprowadzenia tego procesu z krajami tzw. pierwszej transzy (5+1) utworzono specjalną grupę zadaniową Task Force for Accession Negotiations (TFAN); za przeprowadzenie screeningu z pozostałą piątką odpowiedzialna była Dyrekcja Generalna I A Komisji" 29 .

Zgodnie ze schematem sprawdzonym podczas poprzednich negocjacji akcesyjnych, prawodawstwo podzielono na trzydzieści jeden obszarów tema-

\footnotetext{
${ }^{27}$ Przygotowania po stronie polskiej objęły m.in.: a) na mocy ustawy z 8 sierpnia 1996 roku zniesiono urząd Pełnomocnika Rządu ds. Integracji Europejskiej oraz Pomocy Zagranicznej i zamiast niego powołano Komitet Integracji Europejskiej (KIE); b) 28 stycznia 1997 roku Rada Ministrów RP przyjęła „Narodową Strategię Integracji” (NSI); c) w marcu 1997 roku Komitet Integracji Europejskiej, współpracując z administracja rządowa, opracował „Harmonogram Działan Implementacyjnych NSI”, przyjęty przez Radę Ministrów 3 czerwca 1997 roku; d) harmonogram koniecznych do wykonania dostosowań został przyjęty przez Rade Ministrów 23 czerwca 1998 roku w „Narodowym Programie Przygotowania do Członkostwa w Unii Europejskiej” (NPPC); e) W październiku 2001r. Sejm RP podjął uchwałe w sprawie likwidacji Komisji Prawa Europejskiego i Komisji Integracji Europejskiej, a na jej miejsce powołał Komisję Europejską. Por. A. Ambroziak, Proces dostosowania oraz negocjacje Polski o członkostwo w Unii Europejskiej, w: Stosunki Polski z Unia Europejska, Elżbieta Kawecka-Wyrzykowska (red.), Warszawa 2002, s. 118-119 i 123.

${ }^{28}$ Minister spraw zagranicznych Bronisław Geremek w swym wystąpieniu na otwarcie negocjacji w imieniu władz Polski powiedział: „Polska przystępuje do negocjacji z przekonaniem, że członkostwo w Unii Europejskiej jest najkorzystniejszym wyborem z punktu widzenia bezpieczeństwa państwa, stabilności demokratycznego porządku, utrwalania podstaw szybkiego i zrównoważonego rozwoju gospodarczego i budowania nowoczesnego społeczeństwa obywatelskiego. (...) Członkostwo w Unii Europejskiej jest dla Polski szansą i wyzwaniem. Zdajemy sobie sprawę z ogromu czekających nas zadań. Polska w pełni podziela wartości, będące fundamentem, jedności Unii”. Następnie zwrócił uwagę, iż Polska dąży do szybkiego członkostwa w Unii w przeświadczeniu, że będzie to kluczowy element przyspieszonego rozwoju kraju, w: Oświadczenie Rzadu RP na otwarcie negocjacji Polski o członkostwo w UE, w: „Monitor Integracji Europejskiej", nr 18, 1998, s. 85-92.

${ }^{29}$ E. Kawecka-Wyrzykowska, Ewolucja polityki Unii Europejskiej wobec rozszerzenia, w: Stosunki Polski z Unia Europejska, Elżbieta Kawecka-Wyrzykowska (red.), Warszawa 2002, s. 139. Por. J. Hughes, G. Sasse, C. Gordon, dz.cyt., s. 12; P. Nicolaides, Negotiating Effectively for Accession to the European Union: Realistic Expectations, Feasible Targets, Credible Arguments, s. 1-2, dostępne: http://aei.pitt.edu/778/01/scop98_1_2.pdf [15.06.2007].
} 
tycznych. Dwadzieścia dziewięć obszarów zostało poddanych przeglądowi dwukrotnie: podczas wielostronnej i dwustronnej sesji przeglądu prawa. W dwóch obszarach, „Instytucje” oraz „Inne”, negocjacje nie były prowadzone. W pierwszym z nich rozpoczęły się one dopiero po zakończeniu reformy instytucjonalnej, która $\mathrm{w}$ owym czasie byłą dopiero dyskutowana w UE. Głównym negocjatorom przedstawiano także harmonogram przeglądu w poszczególnych obszarach negocjacyjnych. Przegląd ten składał się z dwóch faz - pierwsza z nich miała charakter informacyjny, wielostronny (wspólny dla krajów kandydujących z pierwszej grupy $)^{30}$.

„Początkowo uznano, że dopiero po zakończeniu screeningu ${ }^{31}$ będzie można przejść do negocjacji właściwych. Tymczasem w lipcu 1998 r. KE pod naciskiem Polski zaproponowała krajom kandydującym, aby już na początku września państwa te przedstawiły swoje stanowiska negocjacyjne w siedmiu pierwszych obszarach" ${ }^{\prime 2}$. Zgodnie z kalendarzem negocjacji Polska miała zakończyć przegląd prawa do 1 lipca 1999 r. Na szczycie Rady Europejskiej w Berlinie w marcu tegoż roku podjęto jednak decyzję o zwołaniu dodatkowych sesji we wrześniu. Dotyczyły one dwóch obszarów negocjacyjnych: „Rolnictwa” oraz „Polityki regionalnej i koordynacji instrumentów strukturalnych". Ostatnia sesja przeglądu prawa z udziałem negocjatorów polskich odbyła się 5 listopada $1999 \mathrm{r}$.

Polskie stanowiska negocjacyjne przedstawione $\mathrm{w}$ Brukseli miały charakter wyjściowy i ulegały modyfikacjom w trakcie rokowań. Unia Europejska po zapoznaniu się ze stanowiskiem negocjacyjnym Polski przygotowała odpowiedź w formie wspólnego stanowiska UE. Przyjęty tekst stanowiska Unii, przedstawiany przez stronę unijną delegacjom państw kandydujących na spotkaniu Międzynarodowej Konferencji Akcesyjnej stanowił jednocześnie otwarcie negocjacji w danym obszarze. Po otwarciu obszaru negocjacyjnego strona polska dostarczała Brukseli obszerne wyjaśnienia dotyczące kwestii poruszanych w stanowisku unijnym oraz informacje o po-

\footnotetext{
${ }^{30} \mathrm{Na} 15$ dni przed spotkaniem wielostronnym każde z państw otrzymało dwie listy acąuis communautaire: na liście A znajdowały się akty prawne powszechnie obowiązujące - rozporządzenia, dyrektywy i decyzje, w odniesieniu do których kraje muszą składać odpowiednie deklaracje w fazie dwustronnej; na liście B natomiast znajdowały się dokumenty, które nie były aktami prawnymi, ale miały duże znaczenie dla wyjaśnienia zasad acquis.

${ }^{31}$ „Po każdym screeningu powstawał raport, a następnie odpowiednie zespoły opracowywały tzw. stanowiska negocjacyjne. Były one przygotowywane przez zespół negocjacyjny i przekazywane członkom Komitetu Integracji Europejskiej, a po jego rekomendacji przedstawiane Radzie Ministrów. Po przyjęciu przez rząd stawało się stanowiskiem wyjściowym Polski”, w: J. Kułakowski, Co zostało zrobione, czyli aktualny stan integracji Polski z Unia Europejska, w: Integracja Polski z Unią Europejska. Co każdy Polak wiedzieć powinien, Warszawa 1999, s. 14.

${ }^{32} \mathrm{~J}$. Kułakowski, Polska wobec integracji europejskiej, w: Polska a integracja europejska, Adam Maksymowicz (red.), Wrocław 2000, s. 10.
} 
stępach w realizacji zobowiązań negocjacyjnych, zwłaszcza we wdrażaniu prawa wspólnotowego. Dopiero potem negocjatorzy z Warszawy przedstawiali odpowiedź na unijne stanowiska, która stanowiła podstawę do opracowania przez Komisję Europejską projektu zweryfikowanego wspólnego stanowiska UE. „Jeżeli były one ze sobą zgodne i po stronie UE nie zachodziła obawa, że Polska może nie być w stanie dotrzymać zobowiązań wynikających z własnego stanowiska, dany rozdział tymczasowo zamykano. Jeżeli stanowiska były rozbieżne, przedstawiciele krajów członkowskich ustalali wspólne stanowisko w odniesieniu do polskiego wniosku"33. Całkowite zamkniecie negocjacji równocześnie we wszystkich obszarach nastąpić miało w końcowym etapie rokowań, po uzupełnieniu stanowisk o nowe akty dorobku prawnego UE, które powstawały podczas negocjacji i zweryfikowaniu pozycji przez obie strony ${ }^{34}$.

Polska jako pierwszy kraj kandydujący przedstawił UE stanowiska negocjacyjne w pierwszych siedmiu obszarach. Już 29 października 1998 r. zamknięto tymczasowo trzy obszary negocjacyjne. Kolejne trzy rozdziały zamknięto 10 listopada tegoż roku, a rok 1999 Polska zamknęła z bilansem 29 stanowisk przedłożonych Komisji Europejskiej oraz 9 tymczasowo zamkniętych obszarów negocjacyjnych. Do końca czerwca 2000 r. otwarto rokowania we wszystkich obszarach.

13 grudnia 2002 r., podczas Rady Europejskiej w Kopenhadze, trwały ostatnie negocjacje państw kandydujących do Unii, w tym Polski. Ten dzień przeszedł do historii jako dzień zakończenia rozmów akcesyjnych przez 10 państw Europy Środkowej i Wschodniej ${ }^{35}$. W lutym i w marcu 2003 r. trwały jeszcze ostatnie prace prawników, lingwistów, a także redakcyjne, nad Traktatem Akcesyjnym. 8 kwietnia Rada Ministrów RP wyraziła zgodę na

\footnotetext{
${ }^{33}$ K. Bachmann, Szybko i miękko czy twardo i długo, w: Polska - Unia Europejska. W pót drogi. Wybrane problemy, Marek Cichocki (red.), Warszawa 2002, s. 146.

${ }^{34} 4$ listopada 1998 roku Komisja Europejska przedstawiła pierwszy Raport poświęcony postępom Polski na drodze do członkostwa w Unii. Dokument zwracał uwagę na potrzebę szybszych zmian legislacyjnych dążących do ujednolicenia norm prawnych między Warszawą a Brukselą. W sprawach gospodarczych zalecał rządowi restrukturyzację i prywatyzację.

${ }^{35}$ Premier Leszek Miller tak oto podsumował ten dzień: „Po całodziennych, trudnych i momentami niezwykle dramatycznych negocjacjach wszystkie postulaty, z jakimi przyjechaliśmy do Kopenhagi, zostały przyjęte. Pozwoliło mi to oświadczyć w imieniu polskiego rządu, że przyjmujemy warunki naszego członkostwa w Unii Europejskiej. W ciągu tego dnia, wieńczącego lata trudów i wysiłków, Polska zrobiła wielki historyczny krok. Wierzę głęboko, że nasz naród w pełni zasłużył na tę wielką szansę, jaka otwiera się przed nami i przyszłymi pokoleniami. Zrzucamy z siebie ostatecznie ciężar Jałty i powojennego podziału Europy. Ten sukces jest wspólny. To świadectwo mądrości i dalekowzroczności przywódców europejskich. Wszyscy będziemy odczuwali korzyści płynące z tej decyzji. Taktyka negocjacyjna zdała egzamin. Twarde i zdecydowane rozmowy do ostatniej minuty przyniosły owoce, ale sukces jest wspólny", dostępne: http://www.kprm.gov.pl/2130_7945.htm [15.06.2007].
} 
jego podpisanie. Dzień później, 9 kwietnia, Parlament Europejski wyraził zgodę na przyjęcie do Unii 10 nowych państw (przyjmując w tym celu 10 oddzielnych uchwał), co było bezwzględnym warunkiem przystąpienia. $\mathrm{Za}$ przyjęciem uchwały w sprawie wniosku Polski o członkostwo głosowało 509 deputowanych, 25 było „przeciw”, a 31 wstrzymało się od głosu.

Ówczesny Premier Grecji Costas Simitis, który od 1 stycznia 2003 r. sprawował półroczne rotacyjne przewodnictwo Rady Europejskiej, wystosował do głów państw i szefów rządów krajów członkowskich (i kandydujących) Unii Europejskiej list zapraszający do wzięcia udziału w nieformalnym szczycie Rady Europejskiej, w ceremonii podpisania Traktatu o Akcesji dziesięciu państw do UE oraz w obradach Konferencji Europejskiej (16-17 kwietnia 2003 r., Ateny). Sygnatariuszami Traktatu są głowy państw członkowskich UE, tj. monarchowie w przypadku Belgii, Danii, Hiszpanii, Luksemburga, Holandii, Szwecji i Zjednoczonego Królestwa Wielkiej Brytanii i Irlandii Północnej oraz prezydenci pozostałych ośmiu państw Unii i dziesięciu państw kandydujących ${ }^{36}$. Po podpisaniu Traktat Akcesyjny został złożony w Rzymie, bowiem od 1957 r. depozytariuszem wszystkich modyfikowanych traktatów założycielskich jest rząd włoski.

Począwszy od 16 kwietnia aż do dnia przystąpienia do Unii (1 maja 2004 r.), Polska i pozostałe kraje kandydujące uzyskały status ,aktywnego obserwatora", który umożliwiał uczestnictwo tych państw w kilkuset komitetach Rady UE, Komisji Europejskiej, w Komitecie Stałych Przedstawicieli (tzw. COREPER I - sprawy ekonomiczne i COREPER II - sprawy polityczne), a także udział w posiedzeniach Rady UE oraz Rady Europejskiej. Status "aktywnego obserwatora” pozwalał także na aktywne uczestnictwo w pracach UE (z wygłaszaniem opinii włącznie), jednak do momentu akcesji - bez prawa udziału w podejmowaniu decyzji.

W dniach 7-8 czerwca 2003 r. odbyło się dwudniowe (novum) referendum w sprawie akcesji Polski do UE. Odpowiadano wówczas na pytanie: „Czy wyraża Pan/Pani zgodę na przystąpienie Rzeczypospolitej Polskiej do Unii Europejskiej?". Zwolennicy integracji stanowili zdecydowaną większośćc ${ }^{37}$. Na 9 kwietnia 2004 r. planowano zakończenie procesu ratyfikacji Traktatu Akcesyjnego, co umożliwiło jego wejście w życie z dniem 1 maja tegoż roku. Oznaczało to, pełne członkostwo Polski w UE od tego dnia i umoźliwiało w czerwcu uczestniczenie w wyborach do Parlamentu Europejskiego.

\footnotetext{
${ }^{36}$ Ze strony Polski, w obecności Prezydenta Aleksandra Kwaśniewskiego, podpisy pod Traktatem złożyli: Prezes Rady Ministrów - Leszek Miller, Minister Spraw Zagranicznych - Włodzimierz Cimoszewicz i Minister ds. Europejskich - Danuta Hübner.

${ }^{37}$ Frekwencja wyniosła 58,85\%; za wejściem Polski do UE opowiedziało się 77,45\% głosujących (około 13,5 mln głosujących), przeciw było 22,55\% (około 3,9 mln głosujących).
} 


\section{Zakończenie}

Perspektywa Europy jednoczącej się na zasadach demokracji przedstawicielskiej, obywatelskiej przedsiębiorczości, wolności jednostki i rządów prawa, otworzyła przed Polską najkorzystniejszą koniunkturę polityczną od 300 lat. W 1989 r. Polska przestała być państwem zależnym i tym samym powstały podstawowe warunki dla dalszych zasadniczych wysiłków na rzecz jej politycznej i gospodarczej stabilizacji oraz niezakłóconego rozwoju.

Polskie władze zdecydowały wówczas, że „nie wolno dopuścić do tego, by najważniejszy od dziesiątków lat proces, jaki zachodzi w naszej sferze kulturowej i geopolitycznej, odbywał się bez naszego udziału" ${ }^{38}$. Dlaczego? Ponieważ ze względu na swe geopolityczne położenie, Polska, chcąc nie chcąc, pozostaje i pozostanie w obszarze bezpośredniego politycznego wpływu Unii Europejskiej. Pozostawanie w tej sytuacji poza Unią nie uwolniłoby nas od konieczności znaczących dostosowań prawodawstwa, wynikających z tego sąsiedztwa, ani od możliwości politycznej presji, którą ze względu na swoją przewage gospodarczą i polityczną zachodnia Europa mogłaby wywierać na Polskę. Równocześnie pozostawanie poza UE pozbawiłoby nas politycznych profitów uczestnictwa w podejmowaniu decyzji przez instytucje europejskie.

Jeszcze żaden kraj nie stracił na udziale w integracji europejskiej. Przeciwnie, wszystkie zanotowały osiągnięcia, które nie byłyby w ich zasięgu bez włączenia się do UE. Wielu z nich członkostwo w Unii pozwoliło odgrywać rolę znacznie wykraczającą ponad możliwości wynikające $\mathrm{z}$ własnego potencjału ${ }^{39}$. Przed Polską rysowała się podobna perspektywa, ponieważ „dysponujemy szeregiem atutów, wynikających z położenia geograficznego, potencjału ludnościowego i gospodarczego, własnego dorobku cywilizacyjnego. Nie musimy obawiać się utraty własnej tożsamości. Polska jest zbyt dużym krajem, aby mogło jej grozić takie niebezpieczeństwo. Polska stanęła natomiast przed szansą umocnienia swojej pozycji w regionie i w Europie" ${ }^{40}$.

Intelektualna przekorność nakazuje nam jednak oburzać się za każdym razem, gdy słyszymy, że innej drogi nie było. Oskarżamy o demagogię tych, którzy twierdzą, że jedyną alternatywą był scenariusz białoruski. „Wy-

\footnotetext{
${ }^{38} \mathrm{~J}$. Kułakowski, dz.cyt., s. 11.

${ }^{39}$ Por. G. Falkner, M. Nentwich, Enlarging the European Union: The Short-Term Success of Incrementalism and De-Politicisation, dostępne: http://www.mpifg.de/pu/workpap/wp004/wp00-4.html [15.06.2007]; A. Smith, H. Wallace, The European Union: Towards a Policy for Europe, w: „International Affairs”, nr 3, 1994, s. 429-444.

${ }^{40} \mathrm{~S}$. Stebelski, dz.cyt., s. 20. Por. J. Kułakowski, Co zostało zrobione, czyli aktualny stan integracji Polski z Unia Europejska, w: Integracja Polski z Unia Europejska. Co każdy Polak wiedzieć powinien, Warszawa 1999, s. 15; G.A. Bermann, Law in an Enlarged European Union, dostępne: http://aei.pitt.edu/73/02/bermann.html [15.06.2007].
} 
bór jest zawsze, ale trzeba na rzeczywistość patrzeć chłodnym okiem. Gdy nareszcie nadszedł długo oczekiwany moment, w którym Polska, znająca cenę międzynarodowego ostracyzmu, obojętności, wiedząca czym jest brak suwerenności, mogła sama zdecydować, w którym kierunku chce iść, czy rozsądnym by było zrezygnować z okazji, jaką jest udział w integracji kontynentu? Historia rzadko daje kilka razy jakąś szansę (...)" ${ }^{\prime 41}$. Czy wybrany kierunek był i jest słuszny? Dla znacznej części społeczeństwa polskiego jest oczywiste, że tak. Nie wszyscy jednak muszą podchodzić do integracji europejskiej z entuzjazmem, ale wtedy zwykła chłodna kalkulacja wykaże, że wybór ten był chyba najlepszy z możliwych.

R A F A $€ \quad$ W I L L A

\footnotetext{
${ }^{41} \mathrm{~J}$. Kułakowski, Polska wobec integracji europejskiej, w: Polska a integracja europejska, Adam Maksy-
} mowicz (red.), Wrocław 2000, s. 11. 


\section{The way to the European Union membership - the Polish example}

It is unquestionable that the European integration is a complex and difficult process requiring years to become realised. What is more, it revealed the national interests' differences between western and eastern European countries, which caused the arising of the obstacles, doubts and fears concerning politics, economics and security. However, despite all those facts, or rather simultaneously with them, the possibility of the European Union's eastern enlargement was its biggest challenge ever.

In 1989 Poland has become a fully independent country, and that fact leaded to the arising of the basic conditions for further essential efforts aimed at its political and economic stabilisation and undisturbed development. The perspective of reuniting Europe, respecting the principles of representative democracy, citizens' entrepreneurship, freedom of individuals and the rule of law, has opened the most beneficial political prosperity. Polish government decided to enter the process with hope that it would not cause serious damages to the Polish national interests. Nevertheless, the entry to such a specific organisation as the EU is, required a lot of reforms, changes and efforts from our country's side in order to fulfill all of the conditions enumerated in Copenhagen Treaty from 1993. The article presents the efforts that Poland made to become an equal member of the EU.

Poland stays under the direct political influence of the EU. Exclusion from its structures would not dispense the country from the necessity of the adaptation of law to European norms, from the political pressure executed by the EU because of its position of economic and industrial superiority. Moreover, staying outside the EU would deprive Poland of the political profits coming from the participation in a decision-making process in European institutions. 